\title{
'Findability': A Central Issue for Quality Media in a Networked World
}

\author{
Lizzie Jackson \\ Ravensbourne \\ 6, Penrose Way, London, SE10 OEW \\ Lizzie.jackson@rave.ac.uk
}

\section{KEYNOTE ABSTRACT}

'If Silicon Valley's best minds succeed, their software will not only be listening, it will be understanding and anticipating' (Garside 2014). In January, 2014, Google acquired 'Deep Mind', a UK start up based in London, for $£ 400$ million. Deep Mind specialises in machine learning, advanced algorithms, and systems neuroscience, therefore the company is a natural partner for the global media and information-delivering giant. It appears that Google will soon be augmenting its current model of returning content based on users' previous searches, augmented with paid-for marketing messages, by incorporating enhanced intelligence into its existing search engine 'Hummingbird'.

The rising popularity and affordance of search engines and aggregator sites such as Netflix, YouTube, and Amazon Prime has significant implications for Public Service Media (PSM) across the globe. Providers of quality messages may be to be pushed downwards in user-interface hierarchies and therefore receive less attention. Younger audiences are growing up without a history of consuming public service media (a strong tradition fostered during the Second World War), and consuming linear channels may have little relevance to their own consumption habits. Public service media mostly have very little understanding of the complex systems that drive interactive media. Many PSMs frame their websites as marketing devices or they may face strict competition and copyright laws in their nations, which limit expansion of their online activities. This, it is argued, has serious implications, not only for nations, but for democracy as a whole.

\section{TOWARDS NETWORKED MEDIA}

Search engines and aggregator sites are becoming one of the most dominant methods of accessing media content, 'On any given day in early 2012, more than half of [American] adults using the internet use a search engine (59\%). That is double the $30 \%$ of internet users who were using search engines on a typical day in 2004' (Purcell, Brenner \& Raine 2012). In addition, these sites and services are beginning to operate as production houses, rather than mere distributors. 'House of Cards', originally a BBC mini-series, was re-made exclusively for Netflix, resulting in critical acclaim and awards. Search engines and aggregator sites fundamentally alter the way we consume media; the taxonomy, ranking, and mediation. Marketdriven companies are therefore altering the economic, industrial and cultural landscape.

Pew Internet and Elon University's Imagining the Internet Center carried out an extensive survey with 2,558 experts and technology builders in 2013 and 2014. Digital Life in 2025 concluded there would be a 'Disruption of business models established in the $20^{\text {th }}$ century (most notably impacting finance, entertainment, publishers of all sorts, and education)'. The researchers found consensus in the vision of respondents; a 'global, immersive, invisible, ambient networked computing environment built through the continued proliferation of smart sensors, cameras, software, databases, and massive data centres in a worldspanning information fabric known as the Internet of Things' (Anderson \& Rainie 2014). Information and content will flow seamlessly around us, but how will the overall meaning of those messages be made clear?

\section{MEDIA AND THE PUBLIC GOOD}

The traditional mission of public service media (PSM) has always been to inform, educate and entertain. The value of the PSM enterprise is in ensuring nations have the tools to advocate for change, and the understanding that democratic processes are designed (when they are functioning 
well) as agents of change. Researchers and more worryingly - producers of the PSM enterprise are divided on the urgency of threat. Hendy frames PSM as being 'in surprisingly good form' and able to take advantage of the internet and emerging network distribution systems (Hendy 2013: 127). I would argue that this view is largely coloured by a UK-centric perspective, furthermore, the BBC admits it is facing huge challenges. At the November 2013 Salford Media Festival in Manchester, UK, Victoria Jaye, Head of TV Content for the BBC iPlayer, noted the biggest challenge facing the BBC in the future is 'findability', but add to that, I would argue, findability in the public good.

Many European PSMs are either less able or unable to take advantage of the internet and what it is going to be able to offer in the future. In addition, the relative health of PSMs across Europe is highly variable. The Greek public service broadcaster fell victim to state intervention in June, 2013. Although its journalists continue to broadcast they do so without pay, using their own equipment. Trappel notes PSMs overall watchdog function, however he finds it is weak across Europe with the possible exception of Sweden 'where both public service media and newspapers refer to their roles as watchdogs of power holders' (Trappel 2013:140).

Barnett argues for the continuing importance of Public Service media in order 'to protect the public interest and help to defend against a retreat to the shallow, the sensational, the contrived, or the PR subsidized confection' (Barnett 2011:216). Cushion's 2012 study on the value of PSM supports this by illustrating a direct link between the health of a nation's PSM and the level of awareness of both international and national issues, 'in day-to-day coverage public service media reflect a more diverse and in-depth picture of the world than their commercial counterparts' (Cushion 2012:205). PSMs central function is to enhance the public realm; to make sense of the world, and to help the public locate a sufficiently wide number of high quality elements in order for reification (the making of meaning) to take place; inductive reasoning. Not only that, PSMs have historically provided both commentary and additional material you might not have realised you needed or even wanted. There is an interventionist function that is required for the making of meaning.

\section{THE CHALLENGE TO PUBLIC MEDIA}

The biggest challenge to public service media is that, unlike Google, YouTube, Netflix and Amazon Prime, PSMs are either less able or unable to operate internationally; they are tied to nation states. On the other hand Google claims to 'organise the world's information and make it universally accessible and useful' (Google.com 2014), a statement that indicates a strong commitment to the public realm. Their existing search technology (Hummingbird) tracks previous user requests and patterns in order to predict, and then offer, content likely to interest consumers. The problem is this information may be sold or used by a third party something which Vaidhyanathan terms infrastructural imperialism (Vaidhyanathan 2012:2), and 'the globalisation of a strange kind of surveillance'. According to Couldry 'media play a crucial role in representing the facts and norms that guide our action in the world and, if they do so badly, they can injure the social fabric' (Couldry 2012:210). On the 16th April Mathias Döpfner, the CEO of one of Germany's largest media companies Axel Springer, accused Google of acting like a 'superstate', in an open letter to Eric Schmidt, the Executive Chairman of Google. Döpfner was referring to Google's market and regulatory orientation as seemingly being 'free from the constraints of antitrust regulators and privacy concerns' at the level of individual nations (Vasagar 2014).

\section{RECOMMENDATIONS}

Rather than merely hope commercial aggregator sites and search engines will operate to the same standards public service media embody, I make the following recommendations. Firstly there is a need for the development of an international code of media and communication ethics. There is already a precedent for international cooperation between nations concerning internet-delivered media and communications, namely that countering the activity of paedophiles in order to protect children online. Secondly, in order to maintain the ability of the public to engage in democratic processes, I argue for alliances between public service providers and the dominant global search engines and aggregator sites in order to maintain a balanced flow of quality media and messages. Failing this, commercial providers could be asked to pay a PSM tax where their footprint touches individual nations, this would assist the PSM enterprise to evolve.

The implication of not taking action of any kind to maintain the breadth and quality of messages for the public good is potentially catastrophic. The BBC is currently planning to commercialise its World Service as it is finding financing the service problematic. Underlining the importance of the continuance of the BBC's international arm Helen Goodman, the UK's Shadow culture minister, underlined the significance of access to high quality international news 'in places where this is not otherwise available' (Independent 2014). For citizens living in Greece, Egypt, Syria, Palestine, 
and the Ukraine improving the 'findability' of public service media is a live and critical issue.

\section{REFERENCES}

Anderson, J., and Rainie, L. (2014) Digital Life in 2025. http://www.pewinternet.org/2014/03/11/15theses-about-the-digital-future/ (retrieved 28 April 2014).

Barnett, S. (2012) Broadcast Journalism and Impartiality In the Digital Age' in Lowe, G and Steemers, J (eds.) Regaining the Initiative for Public Service Media, RIPE, 2011, Nordicom: Gothenburg, Sweden.

Couldry, N. (2012) Media, Society, World: Social Theory and Digital Media Practice. Polity Press, Cambridge, UK.

Cushion, S. (2012) The Democratic Value of News: Why Public Service Matter. Palgrave Macmillan: Houndmills, Hampshire, UK.

Garside, J. (2014) Google, Facebook and Amazon race to blur lines between man and machine. http://www.theguardian.com/technology/2014/apr/2 8/google-facebook-amazon-transcendenceartificial-intelligence (retrieved 28 April 2014).

Google.com. (2014) About Google. https://www.google.co.uk/intl/en/about/ (retrieved 10 January 2014).
Hendy, D. (2013) Public Service Broadcasting. Palgrave Macmillan: Houndmills, Hampshire, UK.

Independent (2014) Outrage over commercialisation plans for BBC World Service. http://www.independent.co.uk/artsentertainment/tv/news/outrage-overcommercialisation-plans-for-bbc-world-service9039198.html (retrieved 29 April 2014).

Purcell, K., Brenner, J., and Rainie, L. (2012) Search Engine Use, 2012. http://www.pewinternet.org/Reports/2012/SearchEngine-Use-2012/Summary-of-findings.aspx (retrieved 9 January 2014).

Trappel, J. (2013) 'What Media Value?' in Lowe \& Martin (eds). The Value of Public Service Media: RIPE @ 2013, Nordicom: Gothenburg, Sweden.

Vaidhyanathan, S. (2012) The Googlization of Everything (And Why We Should Worry). Updated Version, eBook, University of California Press: Berkeley and Los Angeles.

Vasagar, J. (2014) Axel Springer accuses Google of seeking digital 'superstate'. http://www.ft.com/cms/s/0/41507d26-c575-11e389a9-00144feabdc0.html\#axzz30CVtZFY1 (retrieved 28 April 2014). 